\title{
A NEW SPECIES OF LOPHIARIS RAF. (ORCHIDACEAE) FROM THE PACIFIC COASTAL OF MEXICO
}

\author{
Ricardo Balam Narváez ${ }^{1,3}$, William Cetzal IX ${ }^{2}$ \\ \& Germán Carnevali Fernández-Concha ${ }^{1}$ \\ ${ }^{1}$ Herbarium CICY, Centro de Investigación Científica de Yucatán, A.C., Calle 43 \# 130, Colonia Chuburná de Hidalgo, \\ Mérida 97200, Yucatán, México \\ ${ }^{2}$ El Colegio de la Frontera Sur, Unidad Chetumal, Av. del Centenario, km 5.5, Chetumal 77000, Quintana Roo, México \\ ${ }^{3}$ Corresponding author: rbn696@hotmail.com
}

\begin{abstract}
A species of Lophiaris Raf. (Orchidaceae: Cymbidieae: Oncidiinae), Lophiaris natalieae, from Jalisco, Mexico, is proposed as new. The new species is described, illustrated and compared to Lophiaris lurida, from which is different by its lateral sepals shortly connate at base, and its transversely narrower central labellum lobe. Its distribution and habitat are discussed. Conservation status of the new taxon is assessed against the MER criteria.

Resumen. Una especie de Lophiaris Raf. (Orchidaceae: Cymbidieae: Oncidiinae), Lophiaris natalieae, de Jalisco, México, es propuesta como nueva. La nueva especie es descrita, ilustrada y comparada con Lophiaris lurida, la cual es diferente por sus sépalos laterales cortos y fusionados en la base, y con el lóbulo central del labelo transversalmente mas estrecho. Su distribución y hábitat son discutidos. El estado de conservación del nuevo taxon es analizado con base a los criterios del MER.
\end{abstract}

Key words: Lophiaris, MER, Mexico, Jalisco, Oncidiinae, Orchidaceae

During the course of a systematic and phylogenetic study of the genus Lophiaris Raf. (Balam et al., in prep.), a hitherto unknown taxon with pale grayish green to light yellow flowers, spotted with dark red to light brown, was detected. It has been collected in Jalisco, Mexico. The presence of a new taxon of Lophiaris in this zone is surprising, since the area is close to some large cities and touristic developments. Only L. oestlundiana (L.O. Williams) Braem, with a differently shaped labellum and matte, brick-red flowers, was previously known from the area.

In accordance with phylogenetic studies of the Trichocentrum Poepp. \& Endl. s.l. complex (for a discussion of generic limits within the Trichocentrum complex see Balam, 2007; Cetzal, 2007; see also discussion and literature citations in JiménezMachorro \& Carnevali, 2001; Cetzal et al., 2008; Carnevali et al., 2009), we place the new species in the genus Lophiaris.

This new entity is probably endemic to the Cabo Corrientes area in NW Jalisco (Pacific Coastal Plain).
This area is notheworthy because of the presence of several species that are either endemic or otherwise mainly restricted there. These include, among the Orchidaceae, taxa such as Lophiaris oestlundiana (L.O. Williams) Braem, Encyclia spatella (Rchb. f.) Schltr., E. trachycarpa (Lindl.) Schltr., Catasetum pendulum Dodson, Mormodes badia Rolfe ex Watson and a few others, including an as yet undescribed species of Cohniella Pfitzer. There are also a few endemic Bromeliaceae such as Tillandsia jaliscomonticola Matuda; T. paucifolia var. schubertii F. Ebel \& J. Röth, and Ursulaea tuitensis (Magaña \& E. J. Lott) Read $\&$ Baensch. The area of Cabo Corrientes is where the Neovolcanic Transversal Axis reaches the Pacific coast, creating barriers to the distribution of biotas from further south and north, while it apparently serves as a corridor for biotas along a west to east axis.

The novelty here proposed, Lophiaris natalieae Balam \& Carnevali, is morphologically similar to $L$. lurida (Lindl.) Braem, which ranges from the Gulf Coastal Plain in Mexico to northeastern Venezuela. The 
differences between these two species are discussed below.

Lophiaris natalieae Balam \& Carnevali, sp. nov.

TYPE: México. Jalisco: Cabo Corrientes, $1.3 \mathrm{~km}$. después del puente Los Horcones, ca. $11 \mathrm{~km}$ después de Boca de Tomatlán, rumbo a El Tuito, $20^{\circ} 26^{\prime} 47^{\prime} \mathrm{N}$ $105^{\circ} 17^{\prime} 05^{\prime \prime} \mathrm{W}, 460-470 \mathrm{~m}$; floreciendo en cultivo en Dzityá, Yucatán, 25 Marzo 2008, de una planta colectada en Julio de 2007, G. Carnevali \& I. Ramírez 7271 (holotype, CICY; isotype, AMES). FIG. 1.

Species haec Lophiaris luridae, sed sepalis lateralibus liberis, callo 5-partito dentibus liberis (vs. 5 partitum, dentibus carina longitudinalis instructis) quam isthmo breviore (vs. subaequans vel longiore), lobulo centrali 2.5-3 x latiore quam longiore (vs 1.5-2) differt.

Epiphytic herb, typical for the genus. Pseudobulbs clustered, subcylindrical, ca. $13.9 \times 10.2 \mathrm{~mm}$, dark or medium green, compressed. Leaves solitary, conduplicate, coarse, $23-24 \mathrm{~cm}$ long, $c a$. 2.4-3.2 $\mathrm{cm}$ wide at the base, $3.3-3.75 \mathrm{~cm}$ in the median portion, and $2.4-2.5 \mathrm{~cm}$ at apex, oblong-elliptic, acute, erect, margins erose-dentate, yellowish olive green or dark green, conspicuously spotted with dark red-brown. Inflorescence paniculate, erect-arching, ca. 33-155 cm long, originating from the base of the mature pseudobulb, one per pseudobulb. Flowers showy, resupinate, $c a .20 .3-24.7 \mathrm{~mm}$ in diameter, the labellum brown-greenish (chocolate), or mustard yellow apically, with a matte texture, basal lobes and isthmus shiny bright red or orange, callus bright red and yellow or light and dark orange with rose-pink, shiny; the bases of the sepals and petals pale grayish green or light yellow, spotted or mottled with dark red o light brown; dorsal sepal clawed, blade rounded-obtuse or rounded-acute, undulate, $5.2-6.6 \times 4.0-7.2 \mathrm{~mm}$, claw $2.5-3.9 \times 1.0-1.7 \mathrm{~mm}$; lateral sepals clawed, shortly connate at base, blade ovate-acute or obovate, $4.7-6.2$ x 3.2-4.9 mm, claw 3.0-4.5 x 1.2-1.8 mm; petals frilled, undulate, swept forward at the apices, blade ovate-oblong, basal portion abruptly narrowed 5.8$6.8 \times 5.2-7.1 \mathrm{~mm}$, claw $2.2-2.9 \times 2.0-2.8$; labellum 9.5-11.8 mm diameter, 3-lobed, pandurate, forming a $135^{\circ}$ angle to the column; the lateral lobes $6-8 \times 1.5-$ $2.5 \mathrm{~mm}$, upper and lower margins reflexed-rounded, subtriangular or subcuadrate when spread; central lobe broadly reniform, $5.5-6.4 \times 11.2-13.8 \mathrm{~mm}$, transversely narrower, shallowly retuse with a minute apiculus; isthmus $1.0-1.5 \times 2.4-3.8 \mathrm{~mm}$, short and narrow; callus $3.2-4.5 \times 2.6-4.4 \mathrm{~mm}$, made up of 5 truncate independent units: two basal units composed of 5-6 teeth, a small pair of porrect teeth at the base of the basal lobes, two lower units which are apically rounded, and a central keel linking the three teeth but not reaching the proximal section of the basal pairs of units. Column 3.4-5.6 x 1.9-3.8 mm, thick and stout dorso-ventrally, luminous white, sometimes touched with pink; the infrastigmatic tabula prominent, subquadrate, yellow, with red-orange blotches; column wings $2.6-3.3 \mathrm{~mm}$ long, dolabriform, the posterior lobe $1.2-2.7 \mathrm{~mm}$ wide, white or pale pink, elongate; stigmatic cavity subquadrate, bright white. Anther $1.3-4.0 \times 2.2-2.9 \mathrm{~mm}$, ovoid, extended into a deep, internally rimmed, visor-like extension at the ventral base, white or yellow-cream, with a thick external keel at the medial portion. Pollinarium $2.9-3.2 \mathrm{~mm}$ long, composed of two obovate-elliptic pollinia, 1.7-2.1 x $1.0-1.6 \mathrm{~mm}$; stipe short, laminar, translucent white, deeply concave with a flaring; viscidium horse shoeshaped. Capsule unknown.

This description was compiled with the use of the herbarium specimens, as well as measurements taken from live or pickled material belonging to the original population.

Paratypes: México. Jalisco: Cabo Corrientes, camino El Tuito-La Chacala, a $4 \mathrm{~km}$ de El Tuito, Selva mediana subperennifolia en buen estado de

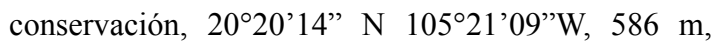
floreciendo en cultivo en Mérida, Yucatán, 13 Marzo 2008, de una planta colectada el 28 de Julio de 2007 (flowers preserved in spirit), R. Balam 104 (CICY); Puerto Vallarta, south of Puerto Vallarta, dry, open forest on top of a hilltop, $400 \mathrm{~m}, 21$ Julio 1987 (flowers preserved in spirit), Warford \& Amezcua s.n. sub. G. Carnevali 6043 (CICY); Tomatlán, 13.5 km después de Horquetas de Caimán, a 9 km después de la desviación a Tomatlán rumbo a Barra de Navidad, $19^{\circ} 42^{\prime} 43^{\prime}$ 'N $, 105^{\circ} 17^{\prime} 54^{\prime \prime} \mathrm{W}, 125 \mathrm{~m}$, floreciendo en cultivo en Dzityá, Mérida, Yucatán, 15 Abril 2007, de una planta colectada el 30 Julio de 2003, G. Carnevali \& I. Ramírez 6931 (CICY). 


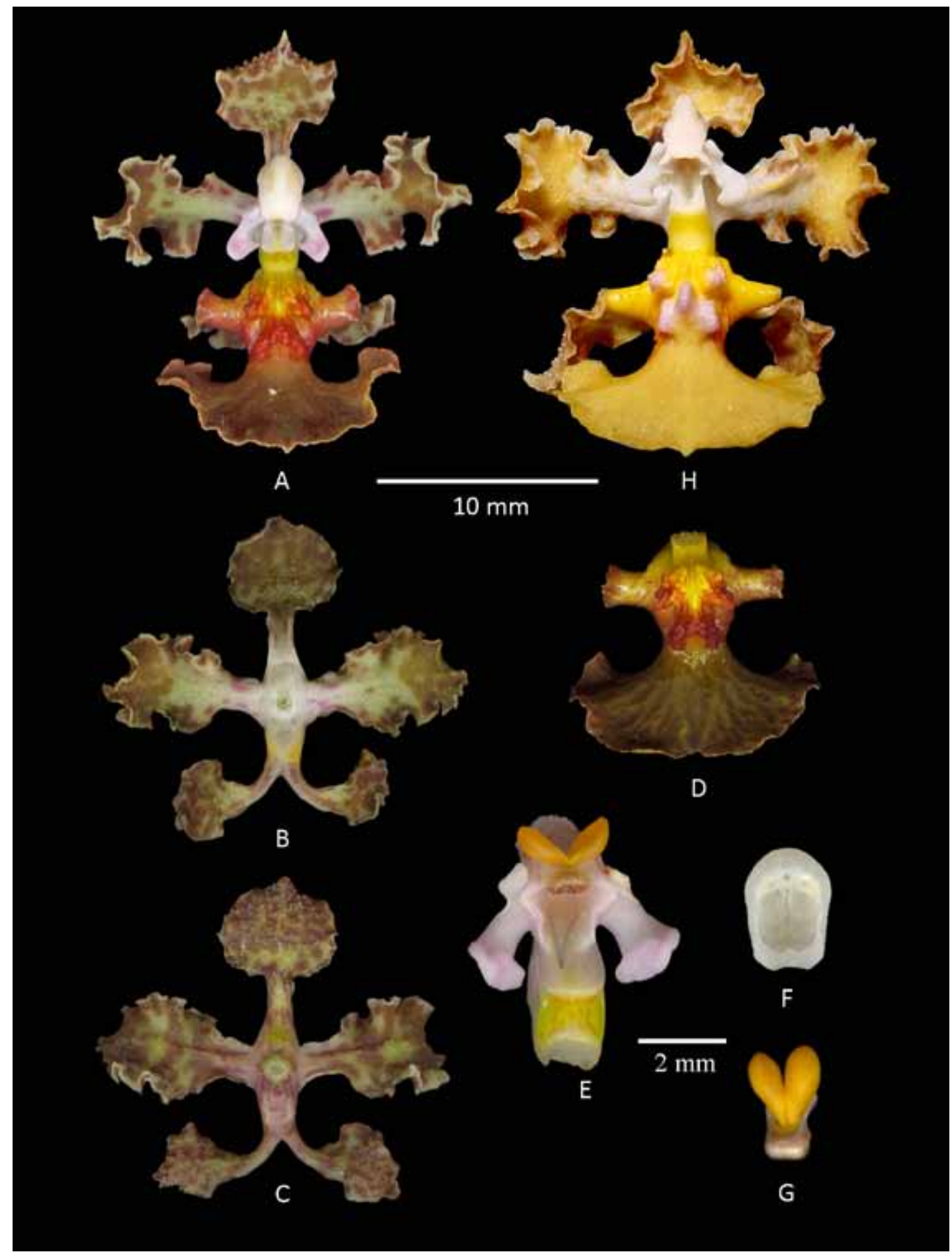

FiguRE 1. Lophiaris natalieae. A-H. Flower. B-C. Sepals and petals, front and back view. D. Labellum. E. Column. F. Anther cap. G. Pollinarium. A-G. Based on R. Balam 104 (CICY). H. Based on G. Carnevali \& I. Ramirez 6931(CICY). Scale: A-D, H. 10 mm; E-G. 2 mm. Assembled by W. Cetzal Ix. 
Eponymy: Dedicated to Natalie Warford, a former resident of Puerto Vallarta, Jalisco, who was the first to recognize the existence of this species as an entity distinct from other Lophiaris species from western Mexico. She cultivated plants and eventually prepared vouchers of this new species, which she also drew beautifully.

Lophiaris natalieae is phenetically similar and apparently phylogenetically related to L. lurida. This last species is restricted to the Gulf drainage in Mexico, extending southwards into Central America and coastal Colombia and Venezuela. Lophiaris natalieae is distinguished from L. lurida by its lateral sepals that are fused on the lower $1 / 4$, while they are free in L. lurida. Furthermore, the central lobe of L. natalieae is transversely narrower than that of $L$. lurida, 2.5-3 times broader than its length in $L$. natalieae while this same structure is $1.5-2$ times broader than long in L. lurida. The calli of both species are also different. In $L$. natalieae the callus is made up of five independent units. These units are variable in shape (rounded to acute) and color (pink to red or yellow), but are always free from each other. On the other hand, L. lurida presents all the structures of the callus associated to a platform over which there are two rows of calli, distal and proximal; these two rows are linked by a medial, longitudinal keel that protrudes beyond the two teeth of the distal row. The distal row of callus in L. lurida reaches (or almost) the base of the central labellum lobe, while the distal row of callus in L. natalieae is placed on the disk and never reaches the isthmus and the base of the central lobe. Another distinction is the size of the flowers; the flower of L. natalieae is much smaller ( $24 \mathrm{~mm}$ vs. 30 $\mathrm{mm}$ in L. lurida).

Distribution AND HABITAT: Lophiaris natalieae seems to be restricted to the western extreme of the Neovolcanic Transversal Axis on the Pacific coast in Jalisco, and to sea facing-slopes along the Pacific Coast of the Sierra Madre Occidental in Nayarit. The known distribution of this species is disjunct, consisting of three sites in Jalisco (Pacific Coastal Plain): one at Cabo Corrientes (southwest of El Tuito) (R. Balam 104), other at Tomatlán (G. Carnevali \& I. Ramírez 6931) and we have had the opportunity of dissecting a flower preserved in spirit from a plant collected south of Puerto Vallarta (Warford \& Amezcua s.n. sub. G. Carnevali 6043). The species has been collected mostly at elevations ranging from $400-600 \mathrm{~m}$ in low caducifolious forest to mediumstatured subcaducifolious forest.

MER RISK CRITERIA. We determined risk status of this new species through the Método de Evaluación del Riesgo de Extinción de las Especies Silvestres en México (Method for the Evaluation of Risk of Extinction for Mexican Wild Species: MER; SEMARNAT 2002) because it has been required by Mexican law since 2002 for listing organisms for protection. This method would provide a reasonably reliable way to identify species of conservation concern and can meet its intended goals of facilitating timely conservation decisions and generating testable hypotheses in future studies. MER methodology consists of four risk criteria, divided into risk categories with numerical scores, with higher numbers denoting higher risk (Tambutti et al. 2001). The total score is calculated by summing the results from its four criteria, establishing a numerical value with which the category of risk of the species is determined: between 12 and 14 are considered in danger of extinction $(\mathrm{P})$; those with a score of 10 or 11 are threatened (A), and those of 9 or below are considered to be of little current risk (Pr) (SEMARNAT 2002). Lophiaris natalieae is known from three isolated localities restricted, where it is uncommon and at low population densities, obtaining total assessment 12 scores. This suggested that it might be best considered danger of extinction (Pr) according to MER criteria (SEMARNAT 2002).

ACKNOWLEDGEMENTS. The authors would like to thank Rolando Jiménez Machorro, of herbarium AMO, who kindly allowed us to proceed with the proposal of this new species. Rodrigo Duno, Lizandro Peraza, and Eliana Noguera critically reviewed and suggestions for improving the manuscript. This research was supported by Consejo Nacional de Ciencia y Tecnología (CONACyT) scholarship, number 167007. CONACyT partially funded this project via grant 49980-Q ("Filogenia molecular y morfológica, revisión sistemática y una exploración de cuatro regiones no-codificantes del genoma del cloroplasto para estudios filogeográficos en el complejo Trichocentrum (Orchidaceae: Cymbidieae: Oncidiinae)". 


\section{LiTERATURE CITED}

Balam, R. 2007. Sistemática y filogenia del género Lophiaris Raf. (Orchidaceae). Tesis de Maestría, Centro de Investigación Científica de Yucatán A.C., Mérida, Yucatán, México. P. 95.

Carnevali, G., R. Duno, G. Romero-González, R. Balam, W. Cetzal, J.L. Tapia-Muñoz \& I.M. Ramírez. 2009. A reappraisal of the turtle-orchids, genus Chelyorchis (Oncidiinae: Orchidaceae): Molecular, phylogenetic, and morphometric approaches. J. Torrey Bot. Soc. 136(2): 164-185.

Cetzal, W. 2007. Filogenia del complejo Trichocentrum. Tesis de Maestría, El Colegio de la Frontera Sur, Chetumal, Quintana Roo, México.

Cetzal-Ix, W., R. Balam \& G, Carnevali. 2008. A new species in Lophiaris (Orchidaceae, Oncidiinae) in the Lophiaris straminea Complex. Novon 18: 12-15.

Jiménez-Machorro, R. \& G. Carnevali. 2001. Nomenclatural notes: New combinations in Lophiaris Raf. (Orchidaceae). Harvard Pap. Bot. 6: 283-284.

SEMARNAT (Secretaría del Medio Ambiente y Recursos Naturales). 2002. Norma Oficial Mexicana NOM-059ECOL-2001. Protección ambiental- Especies nativas de México de flora y fauna silvestres. Categorías de riesgo y especificaciones para su inclusión, exclusión o cambio. Lista de especies en riesgo. Anexo normativo I, método de evaluación del riesgo de extinción de las especies silvestres en México MER. Diario oficial de la federación, segunda sección, 6 de marzo de 2002, México, D.F., México. Pp. 1-81.

Tambutti, M., A. Aldama, O. Sánchez, R. Medellín \& J. Soberón. 2001. La determinación del riesgo de extinción de especies silvestres en México. Gaceta Ecológica 61: 11-21. 